\title{
Depth-Dependent C-N-P Stocks and Stoichiometry in Ultisols Resulting from Conversion of Secondary Forests to Plantations and Driving Forces
}

\author{
Xiaogang Ding ${ }^{1}$, Xiaochuan $\mathrm{Li}^{1}{ }^{1} *$, Ye $\mathrm{Qi}^{1}{ }^{1}$, Zhengyong Zhao ${ }^{2}$, Dongxiao Sun ${ }^{1}$ and Hongxu Wei ${ }^{3,4, *(1)}$ \\ 1 Guangdong Academy of Forestry, Guangzhou 510520, China; 27267152@sinogaf.cn (X.D.); \\ leaqi163@163.com (Y.Q.); 1709301012@st.gxu.edu.cn (D.S.) \\ 2 College of Forestry, Guangxi University, Nanning 530004, China; z.zhao@unb.ca \\ 3 Key Laboratory of Wetland Ecology and Environment, Northeast Institute of Geography and Agroecology, \\ Chinese Academy of Sciences, Changchun 130102, China \\ 4 University of Chinese Academy of Sciences, Beijing 100049, China \\ * Correspondence: gdlylxc@21cn.com.cn (X.L.); weihongxu@iga.ac.cn (H.W.); Tel.: +86-431-8253-6084 (H.W.)
}

check for updates

Citation: Ding, X.; Li, X.; Qi, Y.; Zhao, Z.; Sun, D.; Wei, H. Depth-Dependent C-N-P Stocks and Stoichiometry in Ultisols Resulting from Conversion of Secondary Forests to Plantations and Driving Forces. Forests 2021, 12, 1300. https://doi.org/10.3390/f12101300

Academic Editor: Thomas H. DeLuca

Received: 18 August 2021

Accepted: 21 September 2021

Published: 24 September 2021

Publisher's Note: MDPI stays neutral with regard to jurisdictional claims in published maps and institutional affiliations.

Copyright: (c) 2021 by the authors. Licensee MDPI, Basel, Switzerland. This article is an open access article distributed under the terms and conditions of the Creative Commons Attribution (CC BY) license (https:// creativecommons.org/licenses/by/ $4.0 /)$.

\begin{abstract}
Stocks and stoichiometry of carbon $(\mathrm{C})$, nitrogen $(\mathrm{N})$, and phosphorus $(\mathrm{P})$ in ultisols are not well documented for converted forests. In this study, Ultisols were sampled in 175 plots from one type of secondary forest and four plantations of Masson pine (Pinus massoniana Lamb.), Slash pine (Pinus elliottii Engelm.), Eucalypt (Eucalyptus obliqua L'Hér.), and Litchi (Litchi chinensis Sonn., 1782) in Yunfu, Guangdong province, South China. Five layers of soil were sampled with a distance of $20 \mathrm{~cm}$ between two adjacent layers up to a depth of $100 \mathrm{~cm}$. We did not find interactive effects between forest type and soil layer depth on soil organic carbon (SOC), total nitrogen (TN), and total phosphorus (TP) concentrations and storages. Storage of SOC was not different between secondary forests and Eucalypt plantations, but SOC of these two forest types were lower than that in Litchi, Masson pine, and Slash pine plantations. Soil C:P was higher in Slash pine plantations than in secondary forests. Soil CNP showed a decreasing trend with the increase of soil depth. Soil TP did not show any significant difference among soil layers. Soil bulk density had a negative contribution to soil C and P stocks, and longitude and elevation were positive drivers for soil C, N, and P stocks. Overall, Litchi plantations are the only type of plantation that obtained enhanced C storage in $0-100 \mathrm{~cm}$ soils and diverse $\mathrm{N}$ concentrations among soil layers during the conversion from secondary forests to plantations over ultisols.
\end{abstract}

Keywords: soil stoichiometry; forested land conversion; natural secondary forest; depth-dependent distribution; subtropical forests

\section{Introduction}

The pedosphere reserves the largest carbon (C) sink in terrestrial ecosystem, which contributes to its important role of $C$ sequestration [1,2]. Carbon storage in soils is greater than that in vegetation biomass and atmospheric reservoir combined [3]. Tropical forests locate on the front of the climate curve to balance atmospheric $\mathrm{CO}_{2}$ concentration. About $30 \%$ of global soil C stocks are sequestered in tropical forests [4]. About half of the total C in tropical forests are stored in the upper soils above a depth of $100 \mathrm{~cm}$ [5]. Net primary

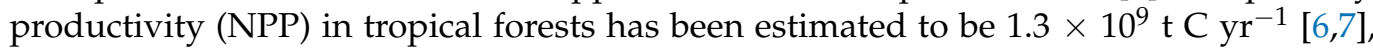
which is about $40 \%$ of the global terrestrial level [8]. Soils in tropical forests also account for the highest $C$ turnover rate [9]. Together, these lead to the uncertainty in estimating $C$ storage levels in tropical forest soils.

Soil nitrogen $(\mathrm{N})$ and phosphorus $(\mathrm{P})$ availabilities strongly influence primary production and $\mathrm{C}$ accumulation. Both $\mathrm{N}$ and $\mathrm{P}$ reserves have a close relationship with $\mathrm{C}$ pools in terrestrial biogeochemical cycles [10]. Soil CNP stoichiometry is a remarkable indicator of 
soil quality, organic composition, $\mathrm{C}$ storage, and $\mathrm{C}$ sequestration in forest ecosystems $[3,11]$. The C:N explains more than $99 \%$ of variations in soil dissolved organic $C$ stock due to its negative relationship with decomposition of soil organic matters [3]. Nitrogen plays a central role in ecosystem productivity and C sequestration [12]. Globally, surface soil $\mathrm{N}$ stocks are estimated to be 133-140 Pg totally for the upper 100-cm and soil C:N are estimated to range from less than 10.0 in Aridisols to over 25.0 in Histosols [13] with a mean ratio of 10.0 [14]. Unlike N, P does not have a gaseous phase. Rock weathering is the primary source of $\mathrm{P}$ in terrestrial ecosystems $[15,16]$. Phosphorus is particularly important in the tropics because $\mathrm{P}$ is adsorbed by oxides and clay minerals which renders $\mathrm{P}$ unavailable to plants [17]. Soil N:P is usually used as an indicator of N-P saturation and relative limitation [18]. Relative to C:N and N:P, less is known about C:P in soil. High C:P may indicate a low microbial diversity and resource quality [19]. There is a lack of attention on the quantification of CNP stoichiometry in tropical forest soils compared to that in other forest ecosystems.

Extensive areas of native forests are being converted into short-rotation plantations to meet increasing demand for timber production [20,21]. Globally, secondary forests are increasingly being converted into plantations, which interrupt soil ecosystems by reducing SOC and lowering nutrient availability [22]. Conversion of tropical secondary forests may drastically impact soil CNP stoichiometry. In the natural forests of Singapore, soil C stock in secondary forests increased to 52\% from 33\% [23]. In Brazil, C and N content in soils were lower in pasture compared to native vegetation stands while $\mathrm{P}$ content was higher, which resulted in a higher C:N but a lower C:P [17]. Even so, current understanding is still limited by three types of information. Specific response of soil CNP stoichiometry has been limited to conversion from secondary forests to a narrow range of plantation types at a regional scale. Depth-dependent change in soil stoichiometry has not received attention regarding specific tropical forest soil types. Topological factors that contribute to soil stoichiometry have not been well documented for tropical forests. As one of main factors that form soil CNP stoichiometry [22], conversion of forest types deserves more attention to further explore changes in soil physicochemical properties.

Ultisols (from Latin ultimus that means 'last') are a type of forest soil that is mainly found in humid tropical areas of the world. Ultisols account for $8.4 \%$ of all soil types in worldwide $[24,25]$. Ultisols have low fertility but a strong ability to leach primary minerals, such as calcium, magnesium, and potassium [25]. Ultisols have a subsurface layer where clays heavily accumulate with an abundant presence of reddish to maroon colored oxidative iron. Therefore, ultisols are recognized as "red clay" in tropical forested lands, such as Amazon Basin, Indonesia, southeastern United States, southern China [25-28]. Because of favorable climate, ultisols usually support productive forests [25]. Prime forests on ultisols have suffered intensive harvests and urbanization. As a result, prime forests are being replaced by secondary forests which are further converted to plantations. Forested Ultisols had greater soil $C$ due to continuous $C$ concentration increase in aggregate [29]. Soil C storage and relevant CNP stoichiometry in successional forests on ultisols are generally unknown.

Soil CNP stoichiometry can vary as a response to different soil depths in broadleaf forests [30]. Depth-dependent attributes have also been documented for texture in ultisols [31]. Forest type and soil depth have an interactive effect on soil stoichiometry during land conversion in subtropical forests [32] and Loess Plateau regions [33]. In this study, CNP stoichiometry was investigated at different soil depths in a secondary forest and four types of plantations in tropical forests on the western mountains of South China. Soils were sampled in a total of 175 plots across five forest types, including a secondary forest and four plantations. Topographical and soil physiochemical properties were also investigated in plots for regression analysis to detect the driving forces that form soil stoichiometry. Our objective was to assess reserves of soil C, N, and P at different depths and to detect their differences, among different forest types, in response to an expected interaction. We hypothesized that, compared to the secondary forest, (i) plantations will have a higher soil 
$\mathrm{C}: \mathrm{N}$ in accordance with decreased $\mathrm{C}$ storage; and (ii) plantations will have lowered soil $\mathrm{N}: \mathrm{P}$ and $\mathrm{C}: \mathrm{P}$, and decreased $\mathrm{P}$ concentration.

\section{Materials and Methods}

\subsection{Study Site}

This study was carried out in Yunfu (latitude: $22^{\circ} 20^{\prime}-22^{\circ} 59^{\prime} \mathrm{N}$, longitude: $111^{\circ} 03^{\prime}-112^{\circ} 31^{\prime} \mathrm{E}$ ), located west of Guangdong province, South China. Regional area is $7785 \mathrm{~km}^{2}$ and $63 \%$ $\left(4915 \mathrm{~km}^{2}\right)$ was forested. The study area is in a subtropical monsoon zone with an annual accumulated temperature between $4500-8000{ }^{\circ} \mathrm{C}$ and an average temperature of $0-15^{\circ} \mathrm{C}$ during the coldest month. Annual rainfall is $1670 \mathrm{~mm}$ and the irradiation period is $1684 \mathrm{~h}[34,35]$. Topography in Yunfu is high in the southwest and low in the northeast, in which mountainous and hilly lands accounted for $61 \%$ and $31 \%$ of the total area, respectively. Natural secondary forest types include evergreen broad-leaved forests, coniferous forests, and mixed coniferous and evergreen-broad leaved forests [31]. Under the impact of anthropogenic activities, some secondary forests have been converted to mixed forests [36]. For example, other broadleaf species were introduced into some tropical native broadleaf forests in Ultisols at Guangdong. In addition, our secondary forests have also been converted to plantations, such as Masson pine (Pinus massoniana Lamb.), Slash pine (Pinus elliottii Engelm.), Eucalypt (Eucalyptus obliqua L’Hér.), and Litchi (Litchi chinensis Sonn., 1782) $[34,37,38]$. Masson pine accounts for one of the largest industrial productions of timber and resin. Eucalypt is a widely planted forest type that accounts for the largest production of timber. Slash pine has been a successfully introduced species that dwell in increasing forested lands that were converted into plantations. Litchi is one of the most important industrial plantations that produce fruits. The most common ultisols in Yunfu include Typic Kanhapludults (Lateritic Red Earths) and Typic Hapludults (Red Earths), which together account for $86 \%$ of forested lands in Yunfu [31].

\subsection{Soil Sampling}

A total of 35 sites were set as stands for soil sampling with seven for secondary forest, 10 for Masson pine, 6 for slash pine, 6 for eucalypt, and 6 for litchi (Figure 1). Specific structure for the five types of forests can be seen in Table S1. Five $20 \mathrm{~m} \times 20 \mathrm{~m}$ plots were laid out for one forest type with every two plots being located at least $50 \mathrm{~m}$ from each other. A total of 175 plots were placed for soil sampling. Five soil profiles from each plot were excavated to $1 \mathrm{~m}$-depth. Soil profiles were divided into five depths of 0-20 cm, 20-40 cm, $40-60 \mathrm{~cm}, 60-80 \mathrm{~cm}$, and $80-100 \mathrm{~cm}$. Soils samples were collected from each depth of a profile and mixed at the same depth for a plot. Soil bulk density (BD) was measured using the cutting ring method at each depth of soil profiles. Plant roots, soil animals, and stones were removed from collected soil samples. Subsequently, soil samples were transported to the laboratory where they were air-dried and sieved through $0.25 \mathrm{~mm}$ to ensure evenness and uniformity.

\subsection{Chemical Analysis}

Soil organic carbon (SOC), total N (TN), and total P (TP) concentrations were measured for samples at $0-20 \mathrm{~cm}, 20-40 \mathrm{~cm}, 40-60 \mathrm{~cm}, 60-80 \mathrm{~cm}$, and 80-100 cm depths separately. The concentration of SOC was determined by the dichromate heating oxidation method [39]. The concentration of TN was determined by the classic Kjeldahl method [40]. The concentration of TP was determined by the molybdenum blue colorimetric method [41]. Soil $\mathrm{pH}$ was measured using a $\mathrm{pH}$ meter.

\subsection{Calculation of Stocks}

Soil stocks $\left(\mathrm{Mg} \mathrm{ha}^{-1}\right)$ for SOC $\left(\mathrm{SOC}_{\text {stock }}\right), \mathrm{TN}\left(\mathrm{TN}_{\text {stock }}\right)$, and TP $\left(\mathrm{TP}_{\text {stock }}\right)$ were calculated as follows [42]:

$$
\begin{aligned}
\mathrm{SOC}_{\text {stock }} & =\mathrm{SOC} \times \mathrm{BD} \times \mathrm{D} / 10, \\
\mathrm{TN}_{\text {stock }} & =\mathrm{TN} \times \mathrm{BD} \times \mathrm{D} / 10,
\end{aligned}
$$




$$
\mathrm{TP}_{\text {stock }}=\mathrm{TP} \times \mathrm{BD} \times \mathrm{D} / 10,
$$

where $\mathrm{BD}$ is the soil bulk density $\left(\mathrm{g} \mathrm{cm}^{-3}\right)$ for the $i$ th layer of soil profile and $\mathrm{D}$ is the depth $(\mathrm{cm})$ of the $i$ th layer of soil. In this study, the variable $i$ stands for any layer from the 5 possible layers in depths of $0-20 \mathrm{~cm}, 20-40 \mathrm{~cm}, 40-60 \mathrm{~cm}, 60-80 \mathrm{~cm}$, and $80-100 \mathrm{~cm}$. Therefore, $\mathrm{D}$ is always a multiple of $20(\mathrm{~cm})$ corresponding to the $i$ th layer.

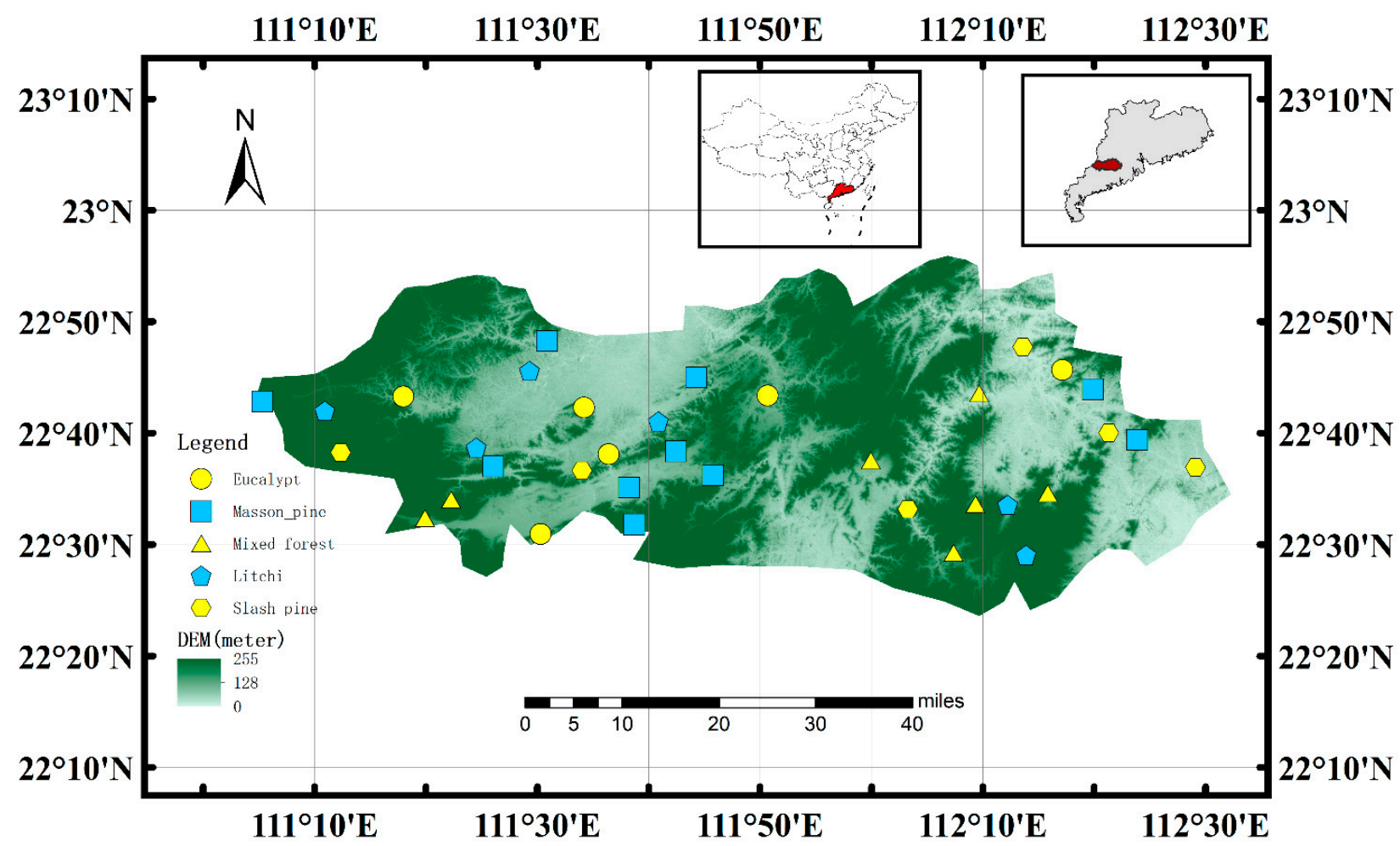

Figure 1. Distribution of stands for soil sampling in forested Ultisols of Yunfu, Guangdong province, South China.

\subsection{Statistical Analysis}

All statistics were analyzed using SAS software (ver. 9.4.0, SAS Institute, Cary, NC, USA). Normality and homogeneity of variance were tested for all observed variables and log-transformed data were used when necessary. Analysis of variance (ANOVA) was used to detect the effects of variation from forest type (degree of freedom $[d f]=4$ ), soil layer $(d f=4)$, and their interaction $(d f=16)$ on concentration and stocks of $C, N$, and $P$ and their concentration ratios (C:N, C:P, N:P) in soils. Only when any interactive effects were identified as significant using ANOVA, were results compared by responses to combined forest-type and soil-layer as two fixed factors. Duncan test was used for comparing the uneven numbers of replicated plots among different forest types. Otherwise, the difference of results across forest type and soil layer were compared by paired $t$-tests when no interaction was indicated by ANOVA. This process detects possible differences by combined factors that two-way ANOVA may fail to find due to accumulated sum of squares. When the main effect was indicated to be significant for either forest type or soil layer, results were compared to detect the difference as a response to either main effect. Significance of difference was defined at the probability of $95 \%(\alpha=0.05)$. To reveal the mechanism that formed CNP stocks by topography and soil properties, stepwise regression was employed to detect combined contributions from longitude, latitude, elevation, slope, soil $\mathrm{pH}$, and soil BD at each of the five depths. Soil stoichiometry was analyzed as dependent variables (responders) and topography and soil property as independent (drivers). Any significant estimate can only be determined in the model when the probability of its contribution was estimated to be higher than $95 \%$. 


\section{Results}

\subsection{Difference among Forest Types}

Forest type was a source of variation mainly for variables of SOC and soil C:P (Table 1). SOC concentration was higher in Litchi, Masson pine, and Slash pine forests than in the secondary forest (Figure 2A). However, differences in SOC concentration were not significant between Eucalypt forests and secondary forests. Accordingly, SOC stock was also higher in Litchi, Masson pine, and Slash pine forests than in secondary forests (Figure 2D). Among the plantations, only Slash pine forests had higher soil C:P compared to secondary forests (Figure 2H). In addition, soil C:P was also higher in Slash pine and Masson pine forests than in Eucalypt forests.

Table 1. Analysis of variance (ANOVA) of forest type $(\mathrm{F})$, soil depth $(\mathrm{S})$, and their interaction $(\mathrm{F} \times \mathrm{S})$ on concentration (conc.), stock, and ratios of soil organic carbon (SOC), total nitrogen (TN), and total phosphorus (TP) in Udults soils among a secondary forest and Eucalypt (Eucalyptus obliqua L'Hér.), Litchi (Litchi chinensis Sonn., 1782), Masson pine (Pinus massoniana Lamb.), and Slash pine (Pinus elliottii Engelm.) plantations at Yunfu, Guangdong, China.

\begin{tabular}{|c|c|c|c|c|c|c|}
\hline \multirow[t]{2}{*}{ Source of Variation } & \multicolumn{2}{|c|}{ SOC Conc. } & \multicolumn{2}{|c|}{ TN Conc. } & \multicolumn{2}{|c|}{ TP Conc. } \\
\hline & $F$ value & $P$ value & $F$ value & $P$ value & $F$ value & $P$ value \\
\hline $\mathrm{F}$ & 5.16 & 0.0004 & 1.19 & 0.3122 & 1.47 & 0.2093 \\
\hline S & 41.75 & $<0.0001$ & 3.84 & 0.0044 & 0.56 & 0.6911 \\
\hline \multirow[t]{3}{*}{$\mathrm{F} \times \mathrm{S}$} & 0.65 & 0.8456 & 0.49 & 0.9511 & 0.15 & 1.0000 \\
\hline & \multicolumn{2}{|c|}{ SOC Stock } & \multicolumn{2}{|c|}{ TN Stock } & \multicolumn{2}{|c|}{ TP Stock } \\
\hline & $F$ value & $P$ value & $F$ value & $P$ value & $F$ value & $P$ value \\
\hline $\mathrm{F}$ & 6.12 & $<0.0001$ & 0.60 & 0.6635 & 0.99 & 0.4128 \\
\hline S & 35.35 & $<0.0001$ & 2.51 & 0.0409 & 0.41 & 0.8049 \\
\hline \multirow[t]{2}{*}{$\mathrm{F} \times \mathrm{S}$} & 0.67 & 0.8221 & 0.53 & 0.9343 & 0.14 & 1.0000 \\
\hline & \multicolumn{2}{|c|}{$\mathrm{C}: \mathrm{N}$} & \multicolumn{2}{|c|}{ C:P } & \multicolumn{2}{|c|}{$\mathbf{N}: \mathbf{P}$} \\
\hline & $F$ value & $P$ value & $F$ value & $P$ value & $F$ value & $P$ value \\
\hline $\mathrm{F}$ & 1.57 & 0.1806 & 3.51 & 0.0077 & 0.39 & 0.8171 \\
\hline S & 5.82 & 0.0001 & 18.27 & $<0.0001$ & 2.72 & 0.0290 \\
\hline $\mathrm{F} \times \mathrm{S}$ & 0.49 & 0.9540 & 0.35 & 0.9915 & 0.31 & 0.9955 \\
\hline
\end{tabular}

Soil TN and TP concentrations fell in a range of 0.92 to 1.17 and 0.27 to 0.32 , respectively, both of which did not differ among forest types (Figure 2B,C). Averaged soil TN stock ranged between $0.26 \mathrm{Mg} \mathrm{ha}^{-1}$ and $0.32 \mathrm{Mg} \mathrm{ha}^{-1}$ and soil TP stock ranged between $0.75-0.90 \mathrm{Mg} \mathrm{ha}^{-1}$ (Figure 2E,F). Soil C:N ranged between 14.8-25.2 and soil N:P ranged from 4.2 to 6.7 (Figure $2 \mathrm{G}, \mathrm{I}$ ).

\subsection{Variation among Soil Layer Depths}

Soil layer significantly affected SOC and TN concentrations and stocks (Table 1). Both SOC concentration and stock showed a decreasing trend with the increase in soil depth (Figure 3A,D). SOC concentration was highest in the surface soil layer (depth of 0-20 cm) and there were no statistically significant differences between layers at depths of $40-60 \mathrm{~cm}$ and $60-80 \mathrm{~cm}$ (Figure 3A). With the increase of soil depth, TN concentration remained unchanged from surface soil to soil at a depth of $40-60 \mathrm{~cm}$. However, TN concentration was lower in soil at depths from $60 \mathrm{~cm}$ to $100 \mathrm{~cm}$ than in surface soil (Figure 3B). Soil TN stock remain unchanged from surface soil to soils at a depth of $60-80 \mathrm{~cm}$ (Figure 3E). Soil TN stock at $80-100 \mathrm{~cm}$ was lower than that at $40-60 \mathrm{~cm}$ and $0-20 \mathrm{~cm}$. Soil TP concentration ranged around $0.3 \mathrm{~g} \mathrm{~kg}^{-1}$ and TP stock ranged around $0.8 \mathrm{Mg} \mathrm{ha}^{-1}$ (Figure 3C,F). 

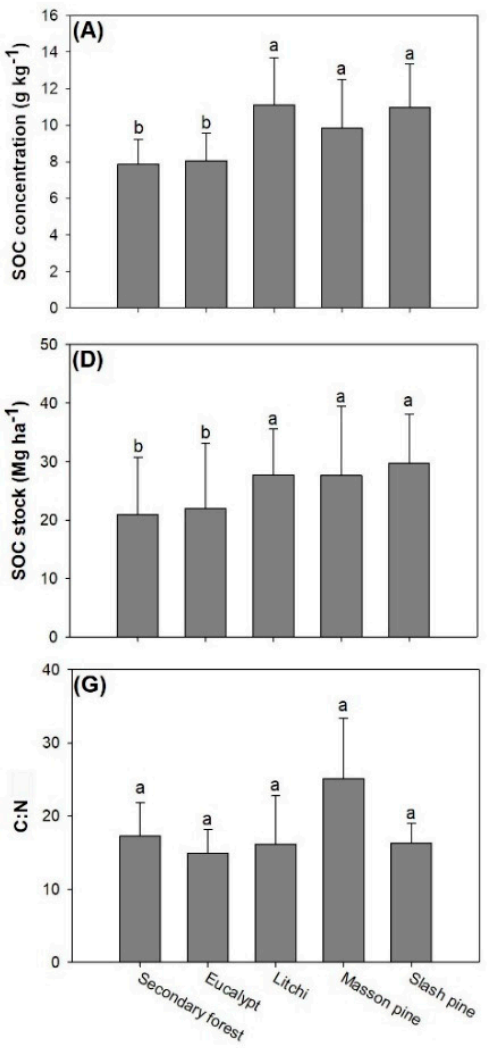
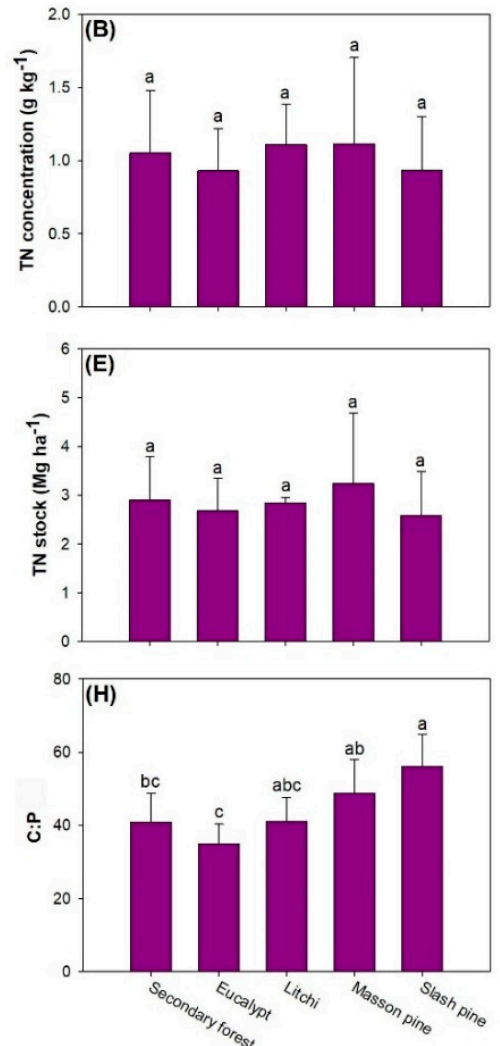
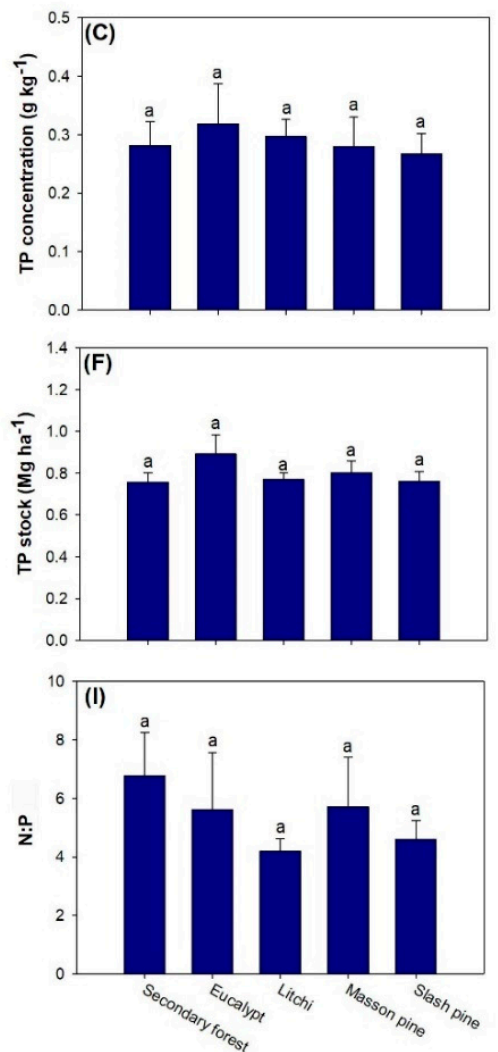

Figure 2. Differences of soil organic carbon (SOC) (A,D), total nitrogen (TN) (B,E), and total phosphorus (TP) (C,F) and ratios of C:N (G), C:P (H), and (N:P) (I) in secondary forests and four types of plantations of Eucalypt (Eucalyptus obliqua L'Hér.), Litchi (Litchi chinensis Sonn., 1782), Masson pine (Pinus massoniana Lamb.), and Slash pine (Pinus elliottii Engelm.) in Yunfu, Guangdong province, South China. Bars indicate standard deviations. Different letters over bars indicate significant difference detected by Duncan test at 0.05 level.

Soil layer also had a significant effect on C:N, C:P, and N:P (Table 1). Soil C:N was higher in soils at depths of $0-20 \mathrm{~cm}$ and $20-40 \mathrm{~cm}$ than that in deeper soils (Figure 3G). Soil C:P showed a decreased trend with the increase of soil depth (Figure $3 \mathrm{H}$ ). Soil C:P was highest in surface soil and C:P was lower at $80-100 \mathrm{~cm}$ than at 20-40 $\mathrm{cm}$ and $40-60 \mathrm{~cm}$. Soil $\mathrm{N}: \mathrm{P}$ was lower at a depth of $80-100 \mathrm{~cm}$ than at $40-60 \mathrm{~cm}$ and $0-20 \mathrm{~cm}$ (Figure 3I).

\subsection{Variation of Concentration along Soil Depths for Different Species}

We did not find any interactive effects of forest type and soil layer on soil variables (Table 1), hence results were analyzed by $t$-tests for soil property concentrations along the depth gradient in different types of plantations (Figure 4). SOC concentration showed a decreasing trend with the increase of soil depth. SOC concentration was higher in surface soil than in deeper soils for most forest types except Eucalypt and Litchi plantations (Figure 4B-1,C-1). There was no difference in SOC concentration at depths of 20-100 cm in secondary forests, but SOC concentration in soil at $80-100 \mathrm{~cm}$ was lower than that in soil at $20-40 \mathrm{~cm}$ and $40-60 \mathrm{~cm}$ in four types of plantations. Soil TN concentration did not show significant difference among soil depths in varied forest types except for that in Litchi plantations (Figure 4C-2). Soil TN concentration at a depth of 60-80 $\mathrm{cm}$ was lower than that in soils at shallower depths. However, TN concentration was not statistically different in soils between $60-80 \mathrm{~cm}$ and $80-100 \mathrm{~cm}$. Soil TP concentration did not show any significant difference among soil depths for any forest type (Figure 4 right column). 

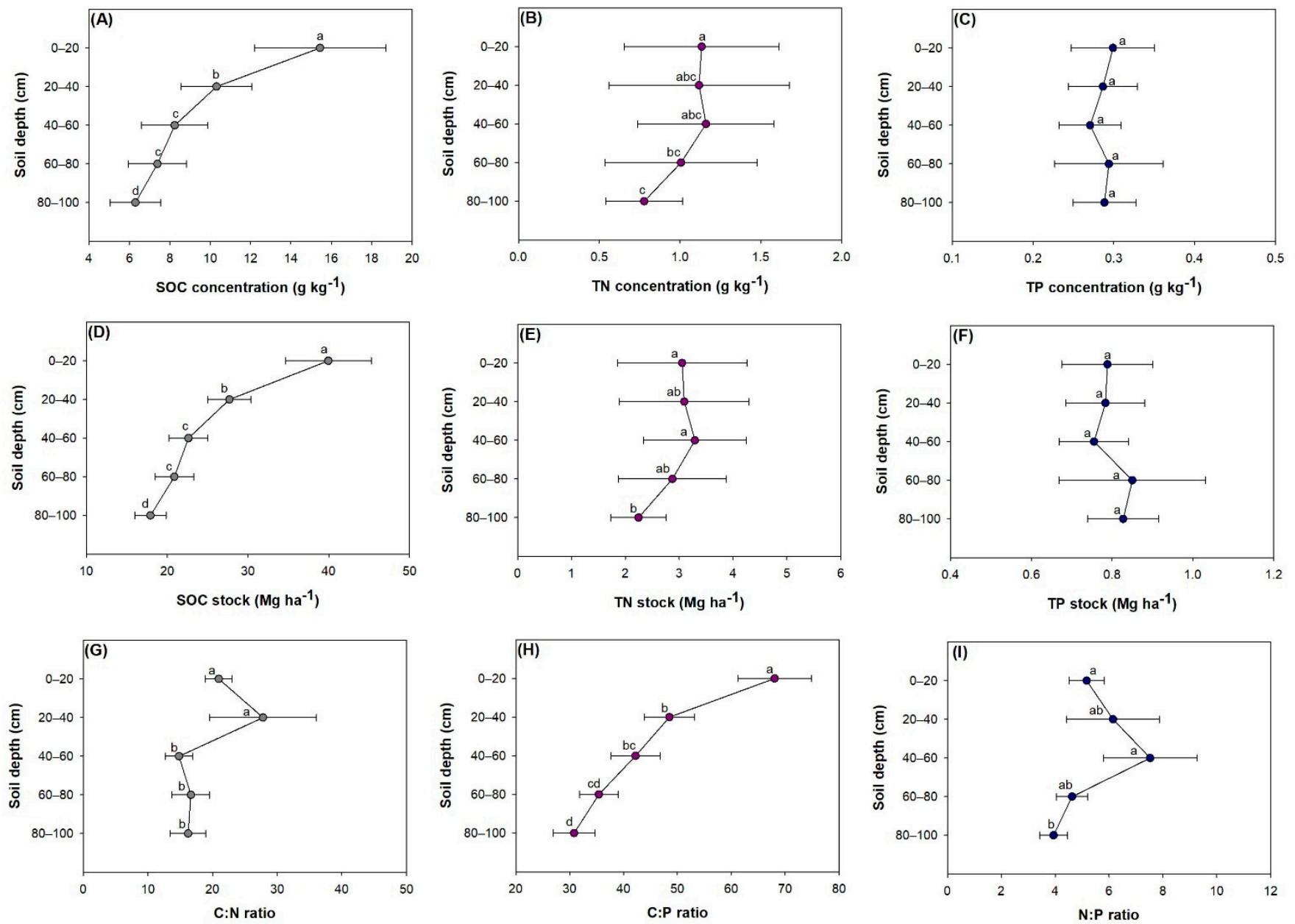

Figure 3. Differences in concentrations and stocks in soil organic carbon (SOC) (A,D), total nitrogen (TN) (B,E), and total phosphorus (TP) $(\mathbf{C}, \mathbf{F})$ and ratios of C:N (G), C:P (H), and (N:P) $(\mathbf{I})$ in five soil layers at depths of 0-20 cm, 20-40 cm, 40-60 cm, 60-80 cm, and 80-100 cm in Yunfu, Guangdong province, South China. Bars indicate standard deviations. Different letters beyond bars indicate significant difference detected by Duncan test at 0.05 level.

\subsection{Variation of Stock along Soil Depths for Different Species}

Again, soil variable stocks were not responsive to interactive effects of forest type and soil layer (Table 1). Therefore, stock results were analyzed by $t$-test and no significant difference was found for most TN and TP stocks at different depths for all forest types (Figure 5). However, in Litchi forests, soil TN stock was lower at $60-80 \mathrm{~cm}$ compared to soil at layers of shallower depths (Figure 5C-2). SOC stock showed a decreasing trend with the increase of soil depth (Figure 5 left column). SOC stock was higher in surface soil than in all other deeper soil layers for secondary forests, Masson pine, and Slash pine plantations. In Eucalypt and Litchi plantations, SOC stock at $80-100 \mathrm{~cm}$ was lower than that at $20-40 \mathrm{~cm}$ and $40-60 \mathrm{~cm}$ (Figure 5B-1,C-1). 

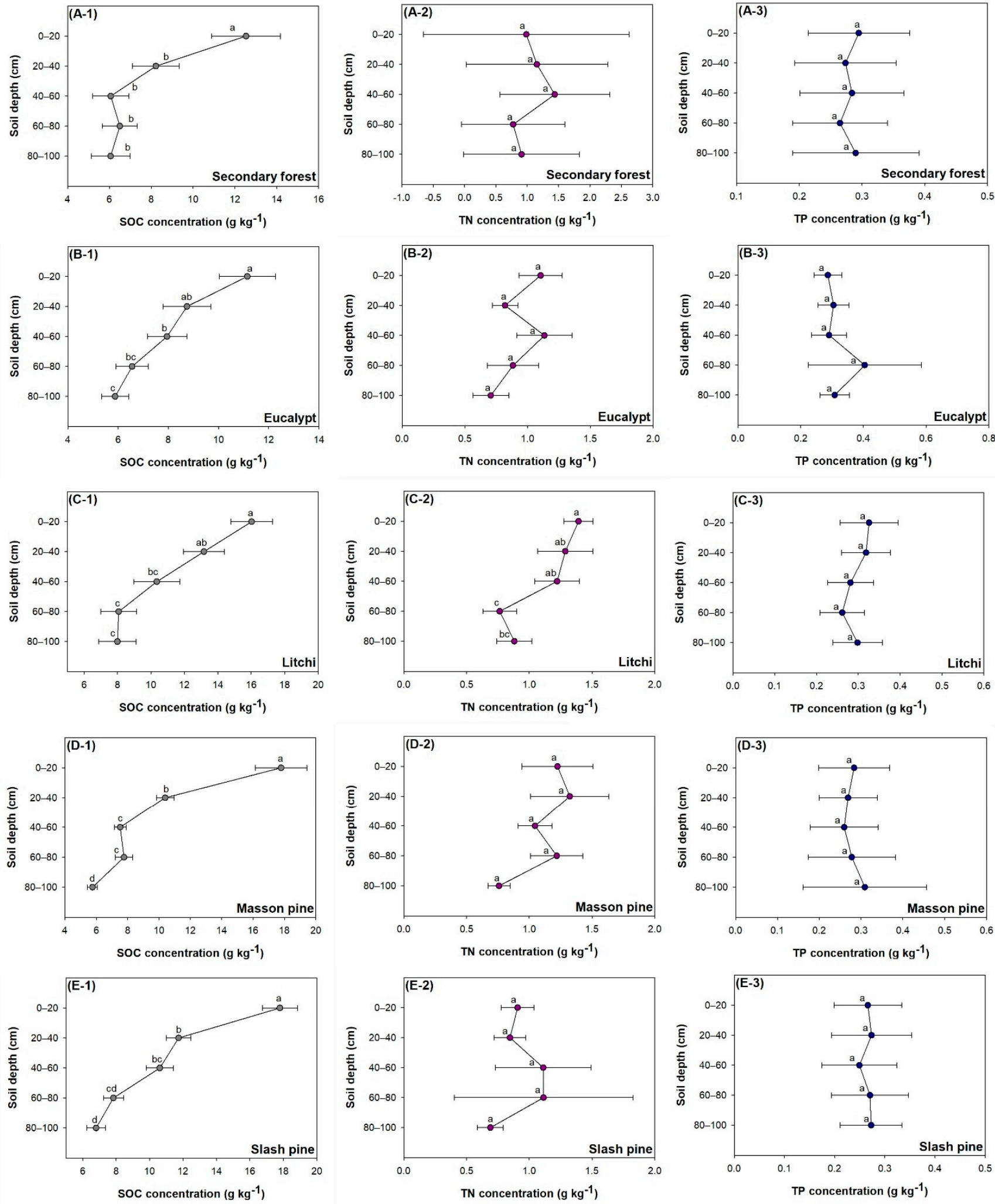

Figure 4. Differences of concentrations in soil organic carbon (SOC) (A-1,B-1,C-1,D-1,E-1), total nitrogen (TN) (A-2,B-2,C2,D-2,E-2), and total phosphorus (TP) (A-3,B-3,C-3,D-3,E-3) in five soil layers at depths of 0-20 cm, 20-40 cm, 40-60 cm, 60-80 cm, and 80-100 cm from stands of secondary forests and four types of plantations of Eucalypt (Eucalyptus obliqua L'Hér.), Litchi (Litchi chinensis Sonn., 1782), Masson pine (Pinus massoniana Lamb.), and Slash pine (Pinus elliottii Engelm.) in Yunfu, Guangdong province, South China, Yunfu, Guangdong province, South China. Bars indicate standard deviations. Different letters beyond bars indicate significant difference detected by paired $t$-test at 0.05 level. 

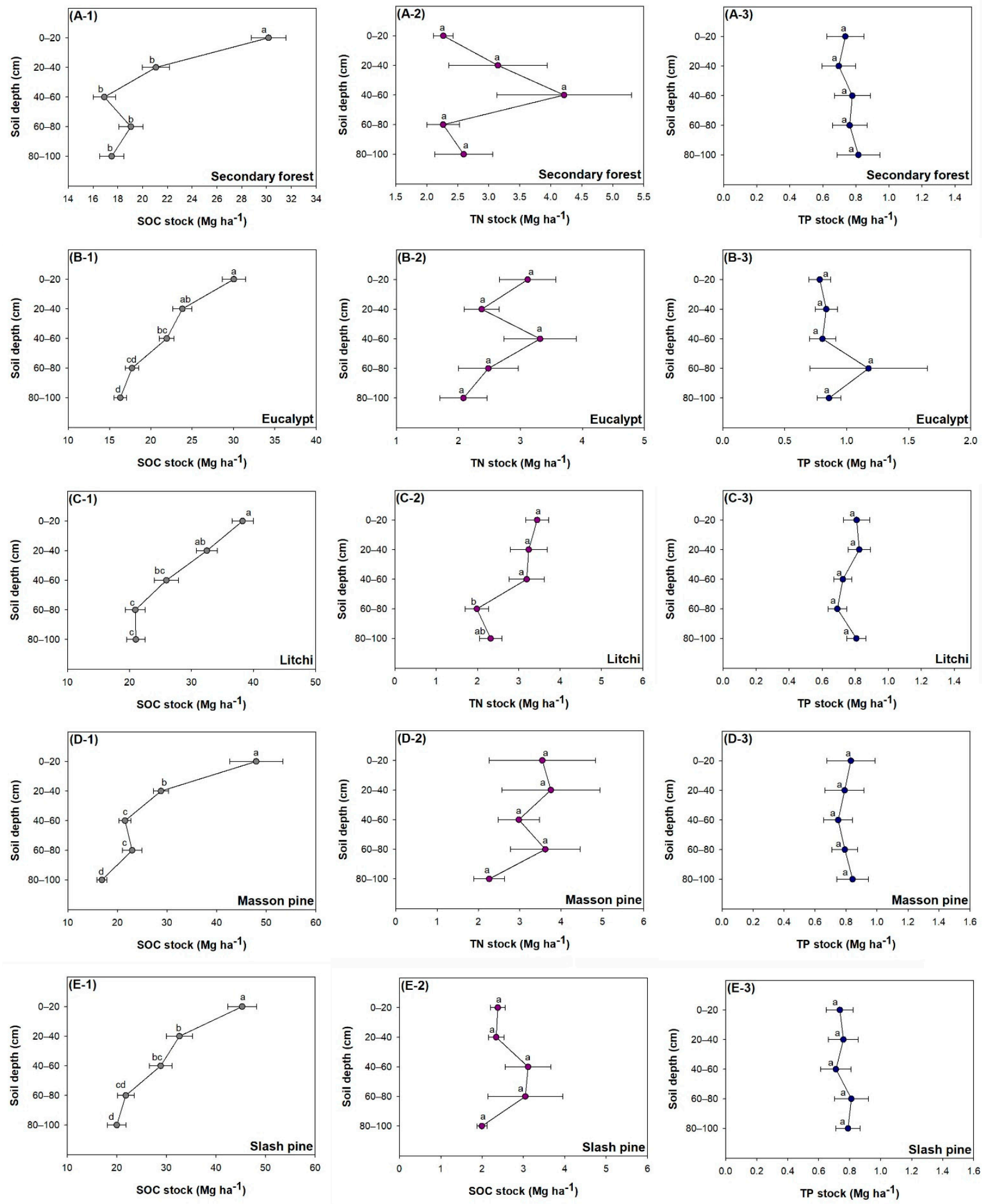

Figure 5. Differences of storages in soil organic carbon (SOC) (A-1,B-1,C-1,D-1,E-1), total nitrogen (TN) (A-2,B-2,C-2,D-2,E-2), and total phosphorus (TP) (A-3,B-3,C-3,D-3,E-3) in five soil layers at depths of 0-20 cm, 20-40 cm, 40-60 cm, 60-80 cm, and 80-100 cm from stands of secondary forests and four types of plantations of Eucalypt (Eucalyptus obliqua L'Hér.), Litchi (Litchi chinensis Sonn., 1782), Masson pine (Pinus massoniana Lamb.), and Slash pine (Pinus elliottii Engelm.) in Yunfu, Guangdong province, South China, Yunfu, Guangdong province, South China. Bars indicate standard deviations. Different letters beyond bars indicate significant difference detected by paired $t$-test at 0.05 level. 


\subsection{Regression of Soil Variable Stock}

Longitude and elevation had positive contributions to SOC stock in surface soil at 0-20 cm (Table 2). Longitude had a greater contribution than elevation when comparing their estimated parameters. In contrast, soil $\mathrm{pH}$ had a negative contribution to surface soil SOC stock. In soil at a depth of $20-40 \mathrm{~cm}$, elevation had a tiny positive contribution to SOC stock, but $\mathrm{BD}$ had a greater positive contribution. Both latitude and $\mathrm{BD}$ had a negative contribution to SOC stock at 40-60 cm, while slope had a tiny positive contribution. Both longitude and elevation had a positive contribution to SOC stock at $60-80 \mathrm{~cm}$. In soil at $80-100 \mathrm{~cm}$, both latitude and BD had negative contributions to SOC stock and slope had a tiny positive contribution.

Table 2. Stepwise regression of surface topology and physicochemical property to soil organic carbon stock in Udults soils at different depths for a secondary forest and Eucalypt (Eucalyptus obliqua L'Hér.), Litchi (Litchi chinensis Sonn., 1782), Masson pine (Pinus massoniana Lamb.), and Slash pine (Pinus elliottii Engelm.) plantations at Yunfu, Guangdong, China.

\begin{tabular}{|c|c|c|c|c|c|}
\hline Variable & Parameter Estimate & SE & Model $\mathbf{R}^{2}$ & $F$ Value & $p$ Value \\
\hline \multicolumn{6}{|c|}{$0-20 \mathrm{~cm}$} \\
\hline Intercept & -624.42 & 292.62 & - & 4.55 & 0.0353 \\
\hline Longitude & 5.90 & 2.59 & 0.1396 & 5.19 & 0.0248 \\
\hline Elevation & 0.02 & 0.01 & 0.0954 & 4.40 & 0.0384 \\
\hline $\mathrm{pH}$ & -5.67 & 2.51 & 0.0564 & 6.15 & 0.0147 \\
\hline \multicolumn{6}{|c|}{$20-40 \mathrm{~cm}$} \\
\hline Intercept & 16.23 & 3.92 & - & 17.09 & $<0.0001$ \\
\hline Elevation & 0.02 & 0.01 & 0.1583 & 19.37 & $<0.0001$ \\
\hline $\mathrm{BD}$ & -6.33 & 2.65 & 0.2029 & 5.71 & 0.0187 \\
\hline \multicolumn{6}{|c|}{$40-60 \mathrm{~cm}$} \\
\hline Intercept & 153.60 & 68.07 & - & 5.09 & 0.0262 \\
\hline Latitude & -6.03 & 3.00 & 0.2162 & 4.04 & 0.0472 \\
\hline Slope & 0.14 & 0.05 & 0.1848 & 6.43 & 0.0127 \\
\hline BD & -8.28 & 2.46 & 0.1334 & 15.86 & 0.0001 \\
\hline \multicolumn{6}{|c|}{$60-80 \mathrm{~cm}$} \\
\hline Intercept & -321.37 & 116.60 & - & 7.60 & 0.0069 \\
\hline Longitude & 2.91 & 1.04 & 0.2239 & 7.82 & 0.0062 \\
\hline Elevation & 0.02 & 0.01 & 0.1645 & 20.27 & $<0.0001$ \\
\hline \multicolumn{6}{|c|}{$80-100 \mathrm{~cm}$} \\
\hline Intercept & 198.09 & 51.37 & - & 14.87 & 0.0002 \\
\hline Latitude & -8.25 & 2.30 & 0.1245 & 14.65 & 0.0002 \\
\hline Slope & 0.09 & 0.04 & 0.1892 & 8.13 & 0.0053 \\
\hline $\mathrm{BD}$ & -4.81 & 2.04 & 0.2317 & 5.59 & 0.0200 \\
\hline
\end{tabular}

Note: BD, soil bulk density.

Topography and soil property only generated significant contribution to TN stock at $80-100 \mathrm{~cm}$ (Table 3). Latitude had a strong negative contribution to TN stock while elevation had a tiny positive contribution.

Table 3. Stepwise regression of surface topology and physicochemical property to total nitrogen stock in Udults soils at the depth of 80-100 cm for a secondary forest and Eucalypt (Eucalyptus obliqua L'Hér.), Litchi (Litchi chinensis Sonn., 1782), Masson pine (Pinus massoniana Lamb.), and Slash pine (Pinus elliottii Engelm.) plantations at Yunfu, Guangdong, China.

\begin{tabular}{cccccc}
\hline Variable & Parameter Estimate & SE & Model R & F Value & $p$ Value \\
\hline Intercept & 22.61 & 11.02 & - & 4.21 & 0.0429 \\
Latitude & -0.97 & 0.49 & 0.1172 & 4.04 & 0.0472 \\
Elevation & 0.01 & 0.01 & 0.0823 & 9.24 & 0.0030 \\
\hline
\end{tabular}

Longitude had a positive contribution to soil TP stock in nearly all soil layers except for the $60-80 \mathrm{~cm}$ layer (Table 4). Soil BD had negative contributions to TP stock at $40-60 \mathrm{~cm}$ and $80-100 \mathrm{~cm}$. 
Table 4. Stepwise regression of surface topology and physicochemical property to total phosphorus stock in Udults soils at different depths for a secondary forest and Eucalypt (Eucalyptus obliqua L'Hér.), Litchi (Litchi chinensis Sonn., 1782), Masson pine (Pinus massoniana Lamb.), and Slash pine (Pinus elliottii Engelm.) plantations at Yunfu, Guangdong, China.

\begin{tabular}{|c|c|c|c|c|c|}
\hline Variable & Parameter Estimate & SE & Model $\mathbf{R}^{2}$ & $F$ Value & $p$ Value \\
\hline \multicolumn{6}{|c|}{$0-20 \mathrm{~cm}$} \\
\hline Intercept & -17.96 & 5.55 & - & 10.48 & 0.0016 \\
\hline Longitude & 0.16 & 0.05 & 0.0952 & 10.83 & 0.0014 \\
\hline \multicolumn{6}{|c|}{$20-40 \mathrm{~cm}$} \\
\hline Intercept & -14.99 & 4.57 & - & 10.76 & 0.0014 \\
\hline Longitude & 0.14 & 0.04 & 0.0979 & 11.18 & 0.0012 \\
\hline \multicolumn{6}{|c|}{$40-60 \mathrm{~cm}$} \\
\hline Intercept & -11.39 & 4.16 & - & 7.48 & 0.0074 \\
\hline Longitude & 0.11 & 0.04 & 0.0640 & 7.04 & 0.0092 \\
\hline $\mathrm{BD}$ & -0.16 & 0.08 & 0.0991 & 3.98 & 0.0488 \\
\hline \multicolumn{6}{|c|}{$60-80 \mathrm{~cm}$} \\
\hline \multicolumn{6}{|c|}{$80-100 \mathrm{~cm}$} \\
\hline Intercept & -11.62 & 4.19 & - & 7.69 & 0.0066 \\
\hline Longitude & 0.11 & 0.04 & 0.0758 & 8.44 & 0.0045 \\
\hline $\mathrm{BD}$ & -0.20 & 0.09 & 0.1214 & 5.29 & 0.0235 \\
\hline
\end{tabular}

\section{Discussion}

\subsection{Failure of Interactive Effects}

Our failure to detect interactive effects between forest type and soil depth on soil stoichiometry does not corroborate findings in subtropical forests [32] and Loess Plateau regions [33]. Although ANOVA did not indicate any significant combination between combined forest-type and soil-depth, paired $t$-tests indicated significant interactions. Many factors can affect the expression of significant interaction and we would like to attribute this to statistics and soil type property. Uneven replicated numbers and insufficient sampling numbers may partly be the cause of this failure. High temperature in tropical forests may also reduce difference in soil stoichiometry among forest types at different depths. Our results clearly demonstrated a weak influence from forest type but a strong influence from depth; hence the latter one contributed to the main body of data variation instead of an interaction with forest type. Soil property in ultisols may have contributed more to $C$ change and subsequently stoichiometry with $\mathrm{N}$ and $\mathrm{P}$ than we expected [31,43]. Overall, the absence of interaction was not surprising, and we do not surmise any repeat investigation will be necessary.

\subsection{Variation among Forest Types}

In this study, we found that SOC was the only responsive variable that was significantly different among the five forest types. Eucalypt was the only type of forest that had similar SOC as secondary forests, and both had lower SOC compared to Litchi, Masson pine, and Slash pine plantations. Studies in subtropical forests have revealed that land conversion from secondary forests to plantations will result in loss of SOC [20,44]. It was also revealed that plantations had higher SOC stock than secondary forests [45]. In regions where soil $\mathrm{C}$ was lost by land conversion to plantations, secondary forests with few disturbances can maintain near-natural forest soil conditions. However, in our study region, secondary forests received frequent management that have heavily disturbed soil $C$ storage. In accordance with our study, another investigation in forests of Queensland, Australia also found no difference in SOC in soils between local secondary forests and Eucalypt plantations [21]. As a fast-growing species, Eucalypt-dominated forests showed similar structure with other types of forests but at lower stand age. The recentness of conversion did not give Eucalypt forests long-enough time to generate different soil $\mathrm{C}$ from secondary forests. It was also documented in Puerto Rico that there was no difference in SOC between 
secondary forests and Pinus caribeae plantations [46]. Therefore, we can accept our results regarding no difference in SOC between secondary forests and Eucalypt forests.

Slash pine forests were the only type of plantations that had higher soil C:P compared to secondary forests. This means that there are lower levels of microbial diversity and resource quality in Slash pine forests [19]. Slash pine are usually managed through straw raking and fertilization [47]. The former is needed for increasing revenue from timber production and the latter replenishes removed $\mathrm{P}$. The change in SOC drove the variation of soil C:P among forest types because soil TP concentration was not changed. Therefore, we surmise it was the stand management that interrupted soil P pool and impacted stand quality in Slash pine forests. In contrast to soil C:P for Slash pine, that in Eucalypt forests was lower, which suggests a better microbial diversity and stand quality. Eucalypt forests were also found to have low $\mathrm{C}: \mathrm{P}$, suggesting a close trend of high nutrient mineralization [48]. High efficiency of nutrient cycling in soils can support the fast-growing attribute of Eucalypt trees.

\subsection{Vertical Distribution across Soil Layers}

In our study, surface soil has a generally higher $C$ stock than deep soils. This trend concurs with studies in Brazil [17] and Singapore [23]. Qiao et al. [30] explained that higher litter accumulation on surface soil provides more dissolved organic $C$, which will also stimulate microbial activity. In contrast, deep soil $\mathrm{C}$ was unstable and might be susceptible to climate-induced perturbation, particularly only if increasing forest productivity promotes $\mathrm{C}$ allocation below-ground [23]. Our gradient of soil C storage was consistent with the gradient in which clay translocated from sandy surface soil to clay subsoil [31]. Although accumulation of clay soils can amend sandy soils by increasing SOC, the increment can only be effective for the surface (depth of 0-30 cm) [49]. More factors can contribute to the negative impact of decline in subsoil SOC rather than just the vertical distribution of soil texture conversion from sandy soil to clay. Surface soil C storage was found to increase with longitude but decrease with $\mathrm{pH}$ value, while SOC in soils at $80-100 \mathrm{~cm}$ was strongly depressed by latitude and bulk density. As local topography is lower in the northeast, flat floor in eastern forests would benefit from litter accumulation and therefore promote $C$ input to surface soil. The negative relationship between soil $\mathrm{pH}$ and $\mathrm{SOC}$ was also found in a large-scale investigation on carbonate soils in China [50]. This might be caused by controlling plant $\mathrm{C}$ transformation in accordance with lower fungal diversity and activity in high soil pH. Lowered SOC storage in deep soils was due to high compaction that would limit fresh organic matter input into subsoil [51]. The flat floor in the northern part of the study area attracted more anthropogenic activities than the hilly lands in the south, which generated heavy pressure on deep soil and limited SOC therein.

Both soil TN concentration and stock were higher in surface soil than in subsoil. The decreasing trend of TN with soil depth accorded with SOC, both of which resulted from a higher input of organic matters into surface soil and lower input in deep soils $[3,30]$. Our TN storage in deep soil at $80-100 \mathrm{~cm}$ was mainly driven by a strong force of latitude as a negative contribution, which concurs with findings on SOC. Soil in northern parts of the study area suffered from lower temperature, which hindered organic matter decomposition and $\mathrm{N}$ mineralization.

Neither soil TP concentration nor stock showed significant vertical distribution among soil layers. This is not the first case of null response to vertical distribution of soil TP in forest soils [3,42]. The vertical distribution pattern of soil TP concentration is the result of synthesized influences by parent material, land use, and biogeochemical processes in the soil ecosystem $[52,53]$. The weathering process of parent materials in surface soil is sensitive to climate and land use, which needs a long period of time and did not show any difference among forest types. Distribution of TP in subsoil is formed not only by longterm weathering of the parent materials but also by translocation from buried plants [54]. Therefore, it was $\mathrm{P}$ accumulation from multiple sources that made TP concentration the same along vertical soil layers. Longitude had a positive contribution to TP stock in most 
soil layers. Our results differed from the trend of soil TP concentration along the longitude at the national scale in China [55]. This contradiction was acceptable because our study sites were concentrated at a regional scale where elevation was lower in the east and higher in the west. Generally, factors impacting soil P along the longitude gradient included soil age, development, climatic condition, and topographic heterogeneity [56-58]. Among these factors, only the topographic variation might have significantly impacted soil P stock along the longitude in our study.

Soil C:N is frequently used as a negative indicator of organic matter decomposition [3] However, our soil C:N showed a decreasing trend with soil depth, which disagrees with other findings in temperature forests [3,59]. In accordance with our results, investigations in other types of subtropical forests also showed higher C: $\mathrm{N}$ in surface soil [30,42]. Nitrogen in organic matters decomposed with $\mathrm{C}$ but the decomposing speed of $\mathrm{N}$ was slower than C. During the decomposition process, soil TN is immobilized in decayed products, leaving behind more durable materials with slower decomposition in deeper soil layers [42].

Again, our soil N:P was higher in soils near surface layers than those in deep layers. These findings were consistent with several previous findings [3,30,42], which together revealed a general response of soil N:P to soil layer depth. In the forest ecosystem of our study, the speed of P mineralization from rock weathering $[15,16]$ was lower than that for $\mathrm{N}$ release from organic matters, which led to a higher $\mathrm{N}$ input than $\mathrm{P}$ input into the soil. Our N:P ranged around 4.0-8.0, which is lower than the Chinese average (9.3) and the global average (13.1) [60]. This suggests $\mathrm{N}$ limitation in our sites, which was more severe in deeper soils than surface soil due to their lower N:P.

\subsection{Vertical Distribution among Differnet Forest Types}

In our study, the vertical distribution of SOC showed a similar pattern among all forest types. Neither TN nor TP were different across soil depths in secondary forests. Litchi plantation was the only type of forest that showed different soil TN concentration and stock at different depths of soil layers. Therefore, it is reasonable to speculate that CNP stoichiometry in Litchi plantations accounted for the most variation across soil depths across all forest types. As one of the most important fruit trees with big economic value, Litchi plantations are always receiving intensive management in southern China [61,62]. Litchi spp. are a heavy N-consumer. Hence, the plantations are frequently dependent on manual $\mathrm{N}$ supply $[61,63]$. Large amount of $\mathrm{N}$ input into soils promoted $\mathrm{N}$ leaching to deep soil and contributed to the variation of TN at different soil depths. In addition, Litchi plantations are also managed by introducing forage grass into the understory to maximize the eco-environment value [64]. Therefore, high biodiversity of undergrowth improved the structure of the soil bacteria community that also strengthened $\mathrm{N}$ mineralization from organic matter decomposition in Litchi plantations.

\section{Conclusions}

We did not observe significant differences in soil CNP stoichiometry by combined forest type and soil type. The Eucalypt plantation was the only forest type to have similar $C$ storage and C:P in soils of the secondary forests. Both SOC and TN storages and C:N, C:P, and N:P in soils showed a generally decreasing trend with the increase of soil depth, but TP storage did not show significant difference along vertical distribution. Litchi plantations were the only type of forest that had a significant difference in TN storage in different soil depths. Overall, during the conversion from secondary forests to plantations over ultisols, Litchi plantations are the only type of plantation that obtained enhanced C storage in 0-100 cm soils and diverse $\mathrm{N}$ concentrations among soil layers.

Supplementary Materials: The following are available online at https://www.mdpi.com/article/10 .3390 / f12101300/s1, Table S1: Structure of five types of forests located in Yunfu, Guangdong province, South China. 
Author Contributions: Conceptualization, X.D. and X.L.; methodology, X.D.; software, H.W.; validation, X.D., Y.Q. and Z.Z.; formal analysis, D.S. and H.W.; investigation, X.D., Y.Q., Z.Z. and D.S.; resources, X.D. and X.L.; data curation, Y.Q. and H.W.; writing-original draft preparation, X.D. and X.L.; writing-review and editing, H.W.; visualization, Z.Z.; supervision, X.D. and X.L.; project administration, X.L.; funding acquisition, X.L. All authors have read and agreed to the published version of the manuscript.

Funding: This research was funded by Guangdong Forestry Science and Technology Plan of China (Grant No.: 201907) and National Natural Science Foundation of China (grant numbers 42001117, 41971122, and 41861017).

Acknowledgments: Authors are thankful to reviewers and editors for their insightful comments and suggestions to an earlier edition of this article.

Conflicts of Interest: The authors declare no conflict of interest.

\section{References}

1. Lal, R. Managing Soils and Ecosystems for Mitigating Anthropogenic Carbon Emissions and Advancing Global Food Security. BioScience 2010, 60, 708-721. [CrossRef]

2. Pires, C.V.; Schaefer, C.E.R.G.; Hashigushi, A.K.; Thomazini, A.; Filho, E.I.F.; Mendonça, E.S. Soil organic carbon and nitrogen pools drive soil C- $\mathrm{CO}_{2}$ emissions from selected soils in Maritime Antarctica. Sci. Total Environ. 2017, 596-597, 124-135. [CrossRef] [PubMed]

3. Cao, Y.; Zhang, P.; Chen, Y.M. Soil C:N:P stoichiometry in plantations of N-fixing black locust and indigenous pine, and secondary oak forests in Northwest China. J. Soils Sediments 2018, 18, 1478-1489. [CrossRef]

4. Jobbagy, E.G.; Jackson, R.B. The vertical distribution of soil organic carbon and its relation to climate and vegetation. Ecol. Appl. 2000, 10, 423-436. [CrossRef]

5. Dixon, R.K.; Brown, S.; Houghton, R.A.; Solomon, A.M.; Trexler, M.C.; Wisniewski, J. Carbon pools and flux of global forest ecosystems. Science 1994, 263, 185-190. [CrossRef]

6. Lewis, S.L.; Lopez-Gonzalez, G.; Sonke, B.; Affum-Baffoe, K.; Baker, T.R.; Ojo, L.O.; Phillips, O.L.; Reitsma, J.M.; White, L.; Comiskey, J.A.; et al. Increasing carbon storage in intact African tropical forests. Nature 2009, 457, 1003. [CrossRef]

7. Malhi, Y. The carbon balance of tropical forest regions, 1990-2005. Curr. Opin. Environ. Sustain. 2010, 2, 237-244. [CrossRef]

8. Beer, C.; Reichstein, M.; Tomelleri, E.; Ciais, P.; Jung, M.; Carvalhais, N.; Rodenbeck, C.; Arain, M.A.; Baldocchi, D.; Bonan, G.B.; et al. Terrestrial Gross Carbon Dioxide Uptake: Global Distribution and Covariation with Climate. Science 2010, 329, 834-838. [CrossRef]

9. Raich, J.W.; Schlesinger, W.H. The global carbon-dioxide flux in soil respiration and its relationship to vegetation and climate. Tellus Ser. B Chem. Phys. Meteorol. 1992, 44, 81-99. [CrossRef]

10. Cleveland, C.C.; Liptzin, D. C:N:P stoichiometry in soil: Is there a "Redfield ratio" for the microbial biomass? Biogeochemistry 2007, 85, 235-252. [CrossRef]

11. Hu, L.; Ade, L.; Wu, X.; Zi, H.; Luo, X.; Wang, C. Changes in Soil C:N:P Stoichiometry and Microbial Structure along Soil Depth in Two Forest Soils. Forests 2019, 10, 113. [CrossRef]

12. Reich, P.B.; Hobbie, S.E.; Lee, T.; Ellsworth, D.S.; West, J.B.; Tilman, D.; Knops, J.M.H.; Naeem, S.; Trost, J. Nitrogen limitation constrains sustainability of ecosystem response to $\mathrm{CO}_{2}$. Nature 2006, 440, 922-925. [CrossRef] [PubMed]

13. Batjes, N.H. Total carbon and nitrogen in the soils of the world. Eur. J. Soil Sci. 1996, 47, 151-163. [CrossRef]

14. Stevenson, F.J.; Cole, M.A. Cycles of Soils: Carbon, Nitrogen, Phosphorus, Sulfur, Micronutrients; John Wiley and Sons: Hoboken, NJ, USA, 1999.

15. Walker, T.W.; Syers, J.K. The fate of phosphorus during pedogenesis. Geoderma 1976, 15, 1-19. [CrossRef]

16. Trudgill, S.T. Soil and Vegetataion Systems; Clarendon Press: Oxford, UK, 1988.

17. Groppo, J.D.; Lins, S.R.M.; Camargo, P.B.; Assad, E.D.; Pinto, H.S.; Martins, S.C.; Salgado, P.R.; Evangelista, B.; Vasconcellos, E.; Sano, E.E.; et al. Changes in soil carbon, nitrogen, and phosphorus due to land-use changes in Brazil. Biogeosciences 2015, 12, 4765-4780. [CrossRef]

18. Fan, H.B.; Wu, J.P.; Liu, W.F.; Yuan, Y.H.; Hu, L.; Cai, Q.K. Linkages of plant and soil C:N:P stoichiometry and their relationships to forest growth in subtropical plantations. Plant Soil 2015, 392, 127-138. [CrossRef]

19. Delgado-Baquerizo, M.; Reich, P.B.; Khachane, A.N.; Campbell, C.D.; Thomas, N.; Freitag, T.E.; Abu Al-Soud, W.; Sorensen, S.; Bardgett, R.D.; Singh, B.K. It is elemental: Soil nutrient stoichiometry drives bacterial diversity. Environ. Microbiol. 2017, 19, 1176-1188. [CrossRef]

20. Wang, Q.; Wang, S.; Yu, X. Decline of soil fertility during forest conversion of secondary forest to Chinese fir plantations in subtropical China. Land Degrad. Dev. 2011, 22, 444-452. [CrossRef]

21. Lewis, T.; Smith, T.E.; Hogg, B.; Swift, S.; Verstraten, L.; Bryant, P.; Wehr, B.J.; Tindale, N.; Menzies, N.W.; Dalal, R.C. Conversion of sub-tropical native vegetation to introduced conifer forest: Impacts on below-ground and above-ground carbon pools. For. Ecol. Manag. 2016, 370, 65-75. [CrossRef] 
22. Wang, Y.; Chen, L.; Xiang, W.H.; Ouyang, S.; Zhang, T.D.; Zhang, X.L.; Zeng, Y.L.; Hu, Y.T.; Luo, G.W.; Kuzyakov, Y. Forest conversion to plantations: A meta-analysis of consequences for soil and microbial properties and functions. Glob. Chang. Biol. 2021. Early Access. [CrossRef]

23. Ngo, K.M.; Turner, B.L.; Muller-Landau, H.C.; Davies, S.J.; Larjavaara, M.; Hassan, N.F.B.; Lum, S. Carbon stocks in primary and secondary tropical forests in Singapore. For. Ecol. Manag. 2013, 296, 81-89. [CrossRef]

24. Lal, R. Soil carbon sequestration to mitigate climate change. Geoderma 2004, 123, 1-22. [CrossRef]

25. University of Idaho. The Twelve Soil Orders: Ultisols. Available online: https://www.uidaho.edu/cals/soil-orders/ultisols\#: \{\}: text=Ultisols $\% 20$ (from $\% 20$ Latin $\% 20$ ultimus $\% 2$ C $\% 20 \% 22$, typically $\% 20$ on $\% 20$ older $\% 2 C \% 20$ stable $\% 20$ landscapes (accessed on 3 January 2021).

26. Wikipedia. The Red Clay Soils: Ultisol. Available online: https://en.wikipedia.org/wiki/Ultisol (accessed on 4 January 2021).

27. Fujii, K.; Uemura, M.; Hayakawa, C.; Funakawa, S.; Sukartiningsih; Kosaki, T.; Ohta, S. Fluxes of dissolved organic carbon in two tropical forest ecosystems of East Kalimantan, Indonesia. Geoderma 2009, 152, 127-136. [CrossRef]

28. Lu, D.; Moran, E.; Mausel, P. Linking amazonian secondary succession forest growth to soil properties. Land Degrad. Dev. 2002, 13, 331-343. [CrossRef]

29. Sotomayor-Ramirez, D.; Espinoza, Y. Soil aggregation and organic carbon fractions in the Rio Grande de Arecibo watershed. J. Agric. Univ. P. R. 2010, 94, 25-39. [CrossRef]

30. Qiao, Y.; Wang, J.; Liu, H.M.; Huang, K.; Yang, Q.S.; Lu, R.L.; Yan, L.M.; Wang, X.H.; Xia, J.Y. Depth-dependent soil C-N-P stoichiometry in a mature subtropical broadleaf forest. Geoderma 2020, 370, 9. [CrossRef]

31. Ding, X.G.; Zhao, Z.Y.; Yang, Q.; Chen, L.N.; Tian, Q.Y.; Li, X.C.; Meng, F.R. Model prediction of depth-specific soil texture distributions with artificial neural network: A case study in Yunfu, a typical area of Udults Zone, South China. Comput. Electron. Agric. 2020, 169, 13. [CrossRef]

32. Luo, X.Z.; Hou, E.Q.; Chen, J.Q.; Li, J.; Zhang, L.L.; Zang, X.W.; Wen, D.Z. Dynamics of carbon, nitrogen, and phosphorus stocks and stoichiometry resulting from conversion of primary broadleaf forest to plantation and secondary forest in subtropical China. Catena 2020, 193, 104606. [CrossRef]

33. Zhao, F.Z.; Zhang, L.; Ren, C.J.; Sun, J.; Han, X.H.; Yang, G.H.; Wang, J. Effect of Microbial Carbon, Nitrogen, and Phosphorus Stoichiometry on Soil Carbon Fractions under a Black Locust Forest within the Central Loess Plateau of China. Soil Sci. Soc. Am. J. 2016, 80, 1520-1530. [CrossRef]

34. Li, X.; Ding, X.; Ceng, S.; Zhang, C.; Yang, H. Forestry Soil Survey of Yunfu, Guangdong Province; China Forestry Publishing House: Beijing, China, 2018.

35. Tang, Z.H.; Ouyang, T.P.; Li, M.K.; Huang, N.S.; Kuang, Y.Q.; Hu, Q.; Zhu, Z.Y. Potential effects of exploiting the Yunfu Pyrite mine (southern China) on soil: Evidence from analyzing trace elements in surface soil. Environ. Monit. Assess. 2019, 191, 1-18. [CrossRef]

36. Wang, W.; Shu, J.; Chen, W.; Ding, J. Holocene environmental changes and human impact in the Yangtze River Delta area in East China. Quat. Sci. 2010, 30, 233-244.

37. Wei, R.-P.; Yang, R.; Wei, Q. Effect of Lime Application to Acidic Soils on Oleoresin Yield Tapped from Pine Plantations in South China. Open J. For. 2014, 4, 390-397. [CrossRef]

38. Anjum, J.; Lone, R.; Wani, K.A. Lychee (Litchi chinensis): Biochemistry, Panacea, and Nutritional Value. In Lychee Disease Management; Kumar, M., Kumar, V., Bhalla-Sarin, N., Varma, A., Eds.; Springer Singapore: Singapore, 2017; pp. $237-256$.

39. Liu, G. Soil Physical and Chemical Analysis, Description of Soil Profiles; Standard Press of China: Beijing, China, 1996.

40. Bremner, J.M.; Mulvaney, C.S. Nitrogen-Total. In Methods of Soil Analysis; American Society of Agronomy: Madison, WI, USA, 1983; pp. 595-624.

41. Murphy, J.; Riley, J.P. A modified single solution method for the determination of phosphate in natural waters. Anal. Chim. Acta 1962, 27, 31-36. [CrossRef]

42. Xu, H.W.; Qu, Q.; Li, P.; Guo, Z.Q.; Wulan, E.; Xue, S. Stocks and Stoichiometry of Soil Organic Carbon, Total Nitrogen, and Total Phosphorus after Vegetation Restoration in the Loess Hilly Region, China. Forests 2019, 10, 27. [CrossRef]

43. Zhao, Z.Y.; Yang, Q.; Sun, D.X.; Ding, X.G.; Meng, F.R. Extended model prediction of high-resolution soil organic matter over a large area using limited number of field samples. Comput. Electron. Agric. 2020, 169, 12. [CrossRef]

44. de Blecourt, M.; Brumme, R.; Xu, J.C.; Corre, M.D.; Veldkamp, E. Soil Carbon Stocks Decrease following Conversion of Secondary Forests to Rubber (Hevea brasiliensis) Plantations. PLoS ONE 2013, 8, e69357.

45. Yang, Y.S.; Xie, J.S.; Sheng, H.; Chen, G.S.; Li, X.; Yang, Z.J. The impact of land use/cover change on storage and quality of soil organic carbon in midsubtropical mountainous area of southern China. J. Geogr. Sci. 2009, 19, 49-57. [CrossRef]

46. Li, Y.; Xu, M.; Zou, X.M.; Shi, P.J.; Zhang, Y.Q. Comparing soil organic carbon dynamics in plantation and secondary forest in wet tropics in Puerto Rico. Glob. Chang. Biol. 2005, 11, 239-248. [CrossRef]

47. Chevasco, E.D.; Minogue, P.J.; Mackowiak, C.; Comerford, N.B. Fertilization and pine straw raking in slash pine plantations: P removals and effects on total and mobile soil, foliage and litter P pools. For. Ecol. Manag. 2016, 376, 310-320. [CrossRef]

48. Bui, E.N.; Henderson, B.L. C:N:P stoichiometry in Australian soils with respect to vegetation and environmental factors. Plant Soil 2013, 373, 553-568. [CrossRef]

49. Schapel, A.; Marschner, P.; Churchman, J. Clay amount and distribution influence organic carbon content in sand with subsoil clay addition. Soil Tillage Res. 2018, 184, 253-260. [CrossRef] 
50. Jin, S.F.; Wang, H.S. Relationships between soil pH and soil carbon in China's carbonate soils. Fresenius Environ. Bull. 2018, 27, 605-611.

51. Brevik, E.; Fenton, T.; Moran, L. Effect of soil compaction on organic carbon amounts and distribution, South-Central Iowa. Environ. Pollut. 2002, 116, S137-S141. [CrossRef]

52. Cheng, Y.; Li, P.; Xu, G.; Li, Z.; Cheng, S.; Gao, H. Spatial distribution of soil total phosphorus in Yingwugou watershed of the Dan River, China. CATENA 2016, 136, 175-181. [CrossRef]

53. Kooijman, A.M.; Jongejans, J.; Sevink, J. Parent material effects on Mediterranean woodland ecosystems in NE Spain. CATENA 2005, 59, 55-68. [CrossRef]

54. Tian, H.; Chen, G.; Zhang, C.; Melillo, J.M.; Hall, C.A.S. Pattern and variation of C:N:P ratios in China's soils: A synthesis of observational data. Biogeochemistry 2010, 98, 139-151. [CrossRef]

55. Zhu, J.; Wu, A.C.; Zhou, G.Y. Spatial distribution patterns of soil total phosphorus influenced by climatic factors in China's forest ecosystems. Sci. Rep. 2021, 11, 5357. [CrossRef]

56. Garcia-Velazquez, L.; Rodriguez, A.; Gallardo, A.; Maestre, F.T.; Dos Santos, E.; Lafuente, A.; Fernandez-Alonso, M.J.; Singh, B.K.; Wang, J.T.; Duran, J. Climate and soil micro-organisms drive soil phosphorus fractions in coastal dune systems. Funct. Ecol. 2020, 34, 1690-1701. [CrossRef]

57. Wang, Y.P.; Law, R.M.; Pak, B. A global model of carbon, nitrogen and phosphorus cycles for the terrestrial biosphere. Biogeosciences 2010, 7, 2261-2282. [CrossRef]

58. Li, X.P.; Chang, S.X.; Liu, J.T.; Zheng, Z.M.; Wang, X.H. Topography-soil relationships in a hilly evergreen broadleaf forest in subtropical China. J. Soils Sediments 2017, 17, 1101-1115. [CrossRef]

59. Zhang, S.; Yan, L.; Huang, J.; Mu, L.; Huang, Y.; Zhang, X.; Sun, Y. Spatial Heterogeneity of Soil C:N Ratio in a Mollisol Watershed of Northeast China. Land Degrad. Dev. 2016, 27, 295-304. [CrossRef]

60. Yang, S.B.; Feng, C.; Ma, Y.H.; Wang, W.J.; Huang, C.; Qi, C.J.; Fu, S.L.; Chen, H.Y.H. Transition from N to P limited soil nutrients over time since restoration in degraded subtropical broadleaved mixed forests. For. Ecol. Manag. 2021, 494, 119298. [CrossRef]

61. Sun, J.; Li, S.; Wei, Z.; Wang, D.; Qi, Z. Distribution of soil nutrients in the litchi orchard in the midwest Hainan. Guangdong Agric. Sci. 2013, 40, 62-64.

62. Yao, L.; Zhou, C.; He, Z.; Li, G.; Yang, B.; Bai, C. Nutrient accumulation characteristics of main litchi cultivars and their relationships with soil nutrients. J. South China Agric. Univ. 2020, 41, 40-47.

63. Menzel, C.M.; Haydon, G.F.; Simpson, D.R. Growth of Lychee (Litchi-chinensis sonn) in sand culture under variable nitrogen supply. J. Horticult. Sci. 1995, 70, 757-767.

64. Zhang, J.E.; Luo, S.M.; Duan, S.S. The eco-environment of a young litchi orchard interplanted with forage grass in south China. In Proceedings of the First International Symposium on Litchi and Longan, Guangzhou, China, 16-19 June 2000; Huang, H., Menzel, C., Eds.; International Society for Horticultural Science: Leuven, Belgium, 2001; pp. 311-313. 